\section{Kidney \\ Blood Pressure Research}

\title{
Significant Association Between Bone- Specific Alkaline Phosphatase and Vascular Calcification of the Hand Arteries in Male Hemodialysis Patients
}

\author{
Eiji Ishimura ${ }^{a}$ Senji Okuno ${ }^{b}$ Hisanori Okazakic Kyoko Norimine ${ }^{b}$ \\ Kenjiro Yamakawab Tomoyuki Yamakawab Shigeichi Shojib Yoshiki Nishizawac \\ Masaaki Inabac
}

aDepartment of Nephrology, Osaka City University Graduate School of Medicine, Osaka 545-8585; bShirasagi Hospital Kidney Center, Osaka 546-0002; 'Department of Endocrinology, Metabolism and Molecular Medicine, Osaka City University Graduate School of Medicine, Osaka 545-8585, Japan

\section{Key Words}

Vascular calcification - Bone formation markers - Bone resorption markers - Bone-specific alkaline phosphatase $\cdot$ Hemodialysis

\begin{abstract}
Background/Aims: Bone-specific alkaline phosphatase (BAP) hydrolyzes pyrophosphate, which inhibits vascular calcification. We examined association between serum BAP and vascular calcification of male hemodialysis patients. Methods: Hand roentgenography of 167 male maintenance hemodialysis patients was conducted, and visible vascular calcification of the hand arteries was evaluated. Serum levels of 3 bone formation markers (BAP, osteocalcin, and $\mathrm{N}$-terminal propeptide of type I collagen) and 2 bone resorption markers (C-terminal telopeptide of type I collagen, and cross-linked N-telopeptide of type I collagen) were measured, along with serum intact parathyroid hormone (PTH). Results: Of 167 patients, visible vascular calcification was seen in 37 patients. Among the bone formation and resorption markers, serum BAP was significantly higher in patients with vascular calcification than in those without $(p<0.05)$; although the other 5 serum bone markers were not significantly different between them. Multivariate logistic regression analyses revealed that log [BAP] was significantly associated with vascular calcification after adjustment for age, hemodialysis duration, presence of diabetes, log [intact PTH] and each of the other 5 bone markers $(p<0.0001)$. Conclusions: Higher serum BAP, but not other bone markers, is significantly associated with the presence of vascular calcification in male hemodialysis patients.
\end{abstract}




\section{Kidney Blood Pressure Research}

\section{Introduction}

Vascular calcification is frequently seen in patients with end-stage kidney disease, and is responsible for the morbidity and mortality in end-stage renal failure [1-4]. Arterial calcification comprises two pathophysiologically distinct disorders: medial calcification (Moenckeberg's arteriosclerosis) and intimal (atherosclerotic) calcification [4, 5]. The incidence of medial calcification is markedly increased in patients with higher age, chronic kidney disease and diabetes [4-6]. While serum calcium and phosphate concentrations have been reported to correlate with the progression of vascular calcification in dialysis patients [7-9], they only partly account for vascular calcification. We previously reported that medial calcification of the hand arteries in hemodialysis patients is advanced in patients with higher age, longer hemodialysis duration, poor glycemic control, and increased inflammatory state $[10,11]$. Although some studies have reported associations between bone loss and vascular calcification [12-17], little is also known about the relationship between bone metabolism markers and vascular calcification, particularly in patients with end-stage renal disease. Recently, the role of alkaline phosphate as an inducer of vascular calcification in renal failure has been demonstrated [18]. Alkaline phosphatase hydrolyzes pyrophosphate, which is a potent inhibitor of vascular calcification $[18,19]$. Serum alkaline phosphatase has been reported to predict mortality among hemodialysis patients [20,21]. While most of these studies examined alkaline phosphatase, little is known about bone-specific alkaline phosphatase (BAP) in relation to vascular calcification. In the present study, we hypothesized that bone turnover markers, in particular, bone specific-alkaline phosphatase, could be associated with vascular calcification and related to vascular calcification in hemodialysis patients.

\section{Patients and Methods}

\section{Patients}

One hundred and sixty seven male hemodialysis patients (age $59.8 \pm 11.8$ years; hemodialysis duration $5.7 \pm 2.9$ years), who had been maintained on stable hemodialysis for more than 3 months at Shirasagi Hospital, Osaka, Japan, were enrolled in the present study after providing written informed consent . In our study protocol, only men were included in order to avoid the influence of the menstrual cycle and menopause on bone metabolism and to ignore possible gender differences among the bone markers. All patients were free of significant acute illness. They had no past history of fracture or radiographic evidence of vertebral or rib fractures. The patients underwent hemodialysis three times per week in 4-h sessions using hollow-fiber dialyzer and bicarbonate dialysate containing 3.0

Fig. 1. Vascular calcification of the hand arteries examined by roentgenography at a voltage of $45 \mathrm{kV}$. The presence of vascular calcification (arrows) was evaluated visually.

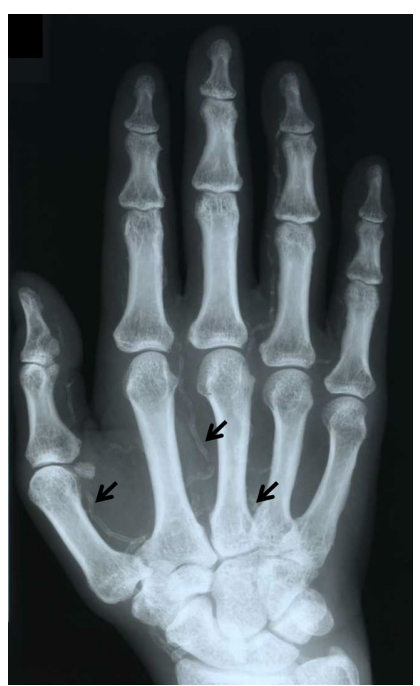
$\mathrm{mEq} / \mathrm{L}$ calcium. This study was approved by the ethics review committee of Shirasagi Hospital.

Assessment of vascular calcification of the hands

Roentgenography of both hands was conducted in each patient at a voltage of $45 \mathrm{kV}$. Apparent visible vascular calcification of the hand arteries distal to the wrist joints was evaluated by one of the authors who was blinded to the other patient data, as reported previously by ourselves (Figure 1) [10, 11].

Measurement of serum parameters and biochemical parameters of bone metabolism Blood was drawn from each patient, just before the start of the dialysis session in a non- 


\section{Kidney \\ Blood Pressure Research}

Kidney Blood Press Res 2014;39:299-307

\begin{tabular}{l|l}
\hline DOI: 10.1159/000355807 & (C) 2014 S. Karger AG, Basel
\end{tabular}

Published onIIne: September 16, 2014

www.karger.com/kbr

301

fasting state. Serum albumin, calcium, and phosphate were measured using routine laboratory methods. Serum calcium was corrected by serum albumin levels, as follows; corrected calcium $[\mathrm{mg} / \mathrm{dl}]=$ measured calcium $[\mathrm{mg} / \mathrm{dl}]+(4.0$ - serum albumin $[\mathrm{g} / \mathrm{dl}])$, when serum albumin was below $4.0 \mathrm{~g} / \mathrm{dl}$. The mean values of six measurements of calcium and phosphate during the 3 months prior to roentgenography were used for analysis. Serum intact parathyroid hormone (intact PTH) was measured by electrochemiluminescence immunoassay (Elecsys PTH, Roche Diagnostics GmbH, Mannheim, Germany) [22]. Serum intact PTH was measured once, at the time of roentgenography. The serum samples were stored in aliquots at $-20^{\circ} \mathrm{C}$ until subsequent assay of bone metabolism markers, with measurements made immediately after thawing. The serum biochemical parameters for bone metabolism were determined, as described previously [22-25]. All serum bone markers were measured in the same assay run, in order to avoid inter-assay variance. As markers of bone formation, serum BAP, N-Terminal propeptide of type I collagen (P1NP), and intact osteocalcin (OC) were measured. Serum BAP was measured, using an enzyme monoclonal antibody used immunoassay kit (Alkphase-B; Metra Biosystem, Mountain View, CA, USA), as reported previously [22, 26, 27]. Intra-assay and inter-assay CVs were $2.2 \%$ and 3.1\%, respectively [22]. Serum P1NP was measured using a competitive radioimmunoassay kit (Orion Diagnostica, Oulunsalo, Finland) [25]. Intra-assay and inter-assay precision values were $2.3 \%$ to $3.5 \%$ and $2.5 \%$ to $5.2 \%$, respectively [25]. Serum OC was assayed using a two-site immunoradiometric assay kit (Mitsubishi Kagaku Bioclinical Laboratories, Tokyo, Japan) that detects only the intact form of OC, and the intra-assay and inter-assay CVs for OC were $6.3 \%$ and $4.0 \%$, respectively [24]. As serum bone resorption markers, serum cross-linked N-telopeptide of type I collagen (NTX) and C-terminal telopeptide of type I collagen (CTX) were measured. Serum NTX was measured by ELISA (Osteomark NTX serum; Ostex International, Seattle, WA, USA), with an intra-assay CV of 4.6\%, as reported previously [22, 23]. Serum CTX was determined by means of the Elecsys $\beta$-CrossLaps/serum assay (Roche Diagnostics, Mannheim, Germany), which is a sandwich immunoassay with two monoclonal antibodies specific for the $\beta$-isomerized 8-amino acid sequence of the C-terminal telopeptide of type I collagen [24]. Intra-assay and inter-assay CVs for serum CTX were $2.6 \%$ and $4.1 \%$, respectively [24].

\section{Statistical methods}

Data are expressed as the mean \pm SD or the median with $25 \%$ - 75\% levels. Mann-Whitney U test was used to compare the serum levels of bone metabolism markers in patients with and without vascular calcification. Logistic regression analysis was performed to examine the association of factors with vascular calcification of the hand arteries. Multivariate logistic analysis was performed to examine the combined influence of the factors associated with vascular calcification of the hand arteries, and to examine the association of BAP with vascular calcification of the hand arteries independent of the other bone markers. Normality of the bone marker variables was assessed to enter multivariate logistic analyses, and intact PTH, BAP, intact OC, P1NP, CTX and NTX were log-transformed to obtain a normal distribution, as the distribution was skewed [22-25]. All calculations were performed on a Windows personal computer using StatView V statistics software (SAS Institute Inc, Cary, NC, USA).

\section{Results}

Clinical characteristics of the patients according to the presence or absence of vascular calcification

Table 1 presents the clinical characteristics of the patients according to the presence and absence of vascular calcification of the hand arteries. The hemodialysis duration of those with vascular calcification was significantly longer than those without vascular calcification $(\mathrm{p}<0.05)$. Compared with non-diabetic patients, vascular calcification was more frequently observed in diabetic patients $(\mathrm{p}<0.0001)$. Intact PTH was significantly lower in patients with vascular calcification than in those without $(\mathrm{p}<0.01)$. There was no significant difference in the prevalence of vitamin $\mathrm{D}$ use between those patients with and without vascular calcification. 


\section{Kidney \\ Blood Pressure Research}

Ishimura/Okuno/Okazaki/Norimine/Yamakawa/Yamakawa/Shoji/Nishizawa/Inaba: Bone Alkaline Phosphatase and Vascular Calcification
Table 1. Clinical characteristics of patients with and without vascular calcification (VC) of the hand

\begin{tabular}{|c|c|c|c|}
\hline & \multicolumn{2}{|c|}{ patients } & \multirow[b]{2}{*}{$\mathrm{p}$} \\
\hline & $\begin{array}{c}\text { without VC } \\
(n=130)\end{array}$ & $\begin{array}{c}\text { with VC } \\
(\mathrm{n}=37)\end{array}$ & \\
\hline age (year) ${ }^{\text {a) }}$ & $59.4 \pm 12.0$ & $61.3 \pm 10.9$ & 0.3798 \\
\hline duration of hemodialysis (year) ${ }^{\text {a) }}$ & $5.5 \pm 2.8$ & $6.8 \pm 2.7$ & 0.0117 \\
\hline diabetes (no / yes) & $104 / 26$ & $9 / 28$ & $<0.0001$ \\
\hline calcium (mg/dl) ${ }^{\text {a) }}$ & $9.0 \pm 0.7$ & $9.1 \pm 0.6$ & 0.4187 \\
\hline phosphate (mg/dl) ${ }^{\text {a) }}$ & $5.7 \pm 1.6$ & $5.3 \pm 1.3$ & 0.0970 \\
\hline intact parathyroid hormone $\left.(\mathrm{pg} / \mathrm{ml})^{\mathrm{b}}\right)$ & $179(81-316)$ & $91(54-212)$ & 0.0089 \\
\hline Vitamin D users (yes / no) & $70 / 60$ & $17 / 20$ & 0.5071 \\
\hline a); mean \pm SD, ; b); median $(25 \%-75$ & levels) & & \\
\hline
\end{tabular}

Fig. 2. Relationship between log [BAP] and other bone metabolism markers after logarithmic transformation. There were strong correlations between log [BAP] and the other bone metabolism markers. BAP: bone-specific alkaline phosphatase, OC: osteocalcin, P1NP: N-terminal propeptide of type I collagen, CTX: C-terminal telopeptide of type I collagen, NTX: cross-linked N-telopeptide of type I collagen.

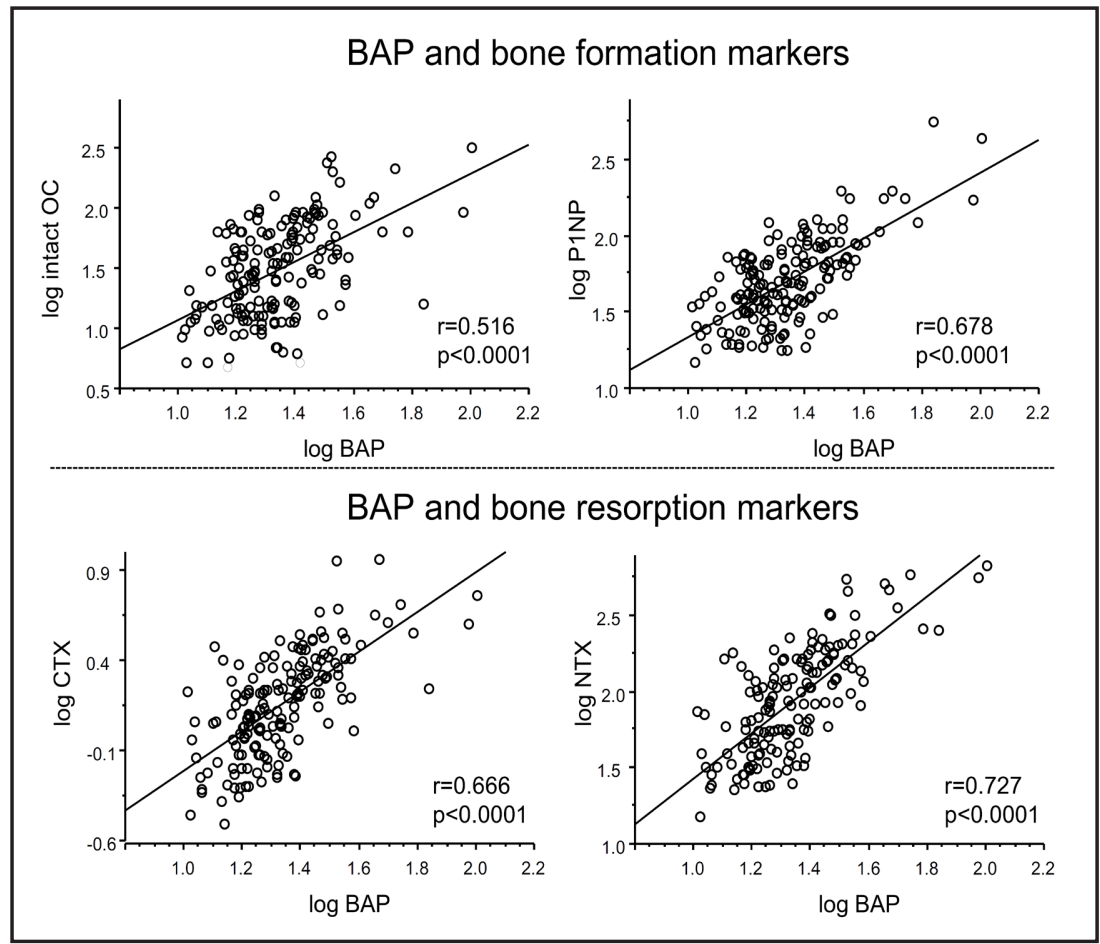

Relation of BAP and other bone metabolism markers with vascular calcification of the hand arteries

The relationships between log [BAP] and other bone markers were examined after logarithmic transformation. There were strong correlations between log [BAP] and the other bone markers (Figure 2).

Serum levels of BAP, OC, P1NP, NTX and CTX were examined in relation to vascular calcification of the hand arteries. As shown in Figure 3, serum BAP was significantly elevated in patients with vascular calcification of the hand arteries compared with those without $(p<0.05)$. However, no significant differences were observed in the serum levels of other bone formation markers of P1NP and intact OC or bone resorption markers of NTX and CTX between those with and without vascular calcification.

Factors associated with vascular calcification

Factors associated with vascular calcification were examined in multivariate logistic regression analyses (Table 2). In Model 1, where BAP was included out of 6 bone markers, significant factors associated with vascular calcification were longer duration of hemodialysis 


\section{Kidney \\ Blood Pressure Research}

Kidney Blood Press Res 2014;39:299-307

DOI: 10.1159/000355807

Published online: September 16, 2014

(C) 2014 S. Karger AG, Basel

www.karger.com/kbr

Ishimura/Okuno/Okazaki/Norimine/Yamakawa/Yamakawa/Shoji/Nishizawa/Inaba: Bone Alkaline Phosphatase and Vascular Calcification

Table 2. Factors associated with vascular calcification of the hand, after adjustment for serum bone marker (logistic regression analysis)

\begin{tabular}{|c|c|c|c|c|c|c|c|c|c|c|}
\hline & \multicolumn{2}{|c|}{ Model 1} & \multicolumn{2}{|c|}{ Model 2} & \multicolumn{2}{|c|}{ Model 3} & \multicolumn{2}{|c|}{ Model 4} & \multicolumn{2}{|c|}{ Model 5} \\
\hline & OR & $\mathrm{p}$ & OR & $\mathrm{p}$ & OR & $\mathrm{p}$ & OR & p & OR & $p$ \\
\hline & \multicolumn{2}{|c|}{$[95 \% \mathrm{CI}]$} & \multicolumn{2}{|c|}{$[95 \% \mathrm{CI}]$} & \multicolumn{2}{|c|}{$[95 \% \mathrm{CI}]$} & \multicolumn{2}{|c|}{$[95 \% \mathrm{CI}]$} & \multicolumn{2}{|c|}{$[95 \% \mathrm{CI}]$} \\
\hline \multirow[t]{2}{*}{ age } & 1.026 & 0.2831 & 1.028 & 0.2471 & 1.028 & 0.2603 & 1.026 & 0.2870 & 1.038 & 0.1509 \\
\hline & \multicolumn{2}{|c|}{ [0.979-1.075] } & \multicolumn{2}{|c|}{ [0.981-1.078] } & \multicolumn{2}{|c|}{ [0.980-1.078] } & \multicolumn{2}{|c|}{ [0.979-1.076] } & \multicolumn{2}{|c|}{ [0.987-1.091] } \\
\hline \multirow[t]{2}{*}{ duration of hemodialysis } & 1.030 & 0.0005 & 1.029 & 0.0009 & 1.029 & 0.0008 & 1.030 & 0.0005 & 1.034 & 0.0004 \\
\hline & \multicolumn{2}{|c|}{ [1.013-1.047] } & \multicolumn{2}{|c|}{ [1.012-1.047] } & \multicolumn{2}{|c|}{ [1.012-1.047] } & \multicolumn{2}{|c|}{ [1.013-1.047] } & \multicolumn{2}{|c|}{ [1.015-1.053] } \\
\hline \multirow[t]{2}{*}{ diabetes (yes vs. no) } & 22.566 & $<0.0001$ & 24.359 & $<0.0001$ & 22.856 & $<0.0001$ & 22.536 & $<0.0001$ & 20.724 & $<0.0001$ \\
\hline & \multicolumn{2}{|c|}{$[6.850-74.341]$} & \multicolumn{2}{|c|}{ [7.081-83.793 } & \multicolumn{2}{|c|}{ [6.930-75.383] } & \multicolumn{2}{|c|}{ [6.840-74.638] } & \multicolumn{2}{|c|}{ [5.913-72.628] } \\
\hline \multirow[t]{2}{*}{ Vitamin D use (yes vs. no) } & 1.090 & 0.8720 & 1.032 & 0.9533 & 1.097 & 0.8619 & 1.089 & 0.8730 & 0.994 & 0.9913 \\
\hline & \multicolumn{2}{|c|}{ [0.383-3.103] } & \multicolumn{2}{|c|}{ [0.358-2.980] } & \multicolumn{2}{|c|}{ [0.385-3.125] } & {$[0.38$} & $3.104]$ & {$[0.32$} & .088] \\
\hline $\log [$ intact PTH] & 0.140 & 0.0056 & 0.108 & 0.0079 & 0.133 & 0.0054 & 0.139 & 0.0144 & 0.069 & 0.0044 \\
\hline & {$[0.0$} & 0.5562 & {$[0.02$} & 0.5568 & {$[0.0$} & .550] & {$[0.0$} & $0.675]$ & {$[0.01$} & .436] \\
\hline $\log [\mathrm{BAP}]$ & 366.784 & 0.0011 & 239.221 & 0.0044 & 208.383 & 0.0150 & 356.952 & 0.0068 & 310.940 & 0.0245 \\
\hline & {$[10.60$} & ,688.524] & {$[5.535-$} & ,339.838] & {$[2.846-$} & 56.345] & {$[5.074$} & ,112.978] & {$[2.092-4$} & 18.228] \\
\hline $\log [$ intact OC] & ----- & ----- & 1.850 & 0.5578 & ------ & ----- & ------ & ----- & ----- & ----- \\
\hline & & & {$[0.23$} & 14.483] & & & & & & \\
\hline $\log$ [intact P1NP] & ------ & ------ & ---- & ----- & 1.790 & 0.6531 & ------ & ------ & ------ & ----- \\
\hline & & & & & {$[0.14$} & $.668]$ & & & & \\
\hline $\log [$ СТX $]$ & ----- & ------ & -..--.- & ------ & ----- & ----- & 1.033 & 0.9820 & -----. & ----- \\
\hline & & & & & & & {$[0.06$} & 16.789 & & \\
\hline $\log [\mathrm{NTX}]$ & ----- & ------ & ------ & ----- & ------ & ----- & ----- & ----- & 2.613 & 0.5338 \\
\hline & & & & & & & & & {$[0.127$} & $3.841]$ \\
\hline & $\mathrm{R}^{2}=0.4$ & $\mathrm{p}<0.0001$ & $\mathrm{R}^{2}=0.41$ & $\mathrm{p}<0.0001$ & $\mathrm{R}^{2}=0.41$ & $<0.0001$ & $\mathrm{R}^{2}=0.41$ & $\mathrm{p}<0.0001$ & $\mathrm{R}^{2}=0.43$ & $<0.0001$ \\
\hline
\end{tabular}

Fig. 3. Serum levels of markers of bone formation markers and bone resorption markers in patients with $(\mathrm{VC}(+))$ and without vascular calcification (VC(-)). Bone specific alkaline phosphatase (BAP) was significantly higher in those with $\mathrm{VC}(+)$ than in those without VC $(-)(\mathrm{p}<0.05)$. However, no significant differences were observed in serum levels of other bone formation markers of N-Terminal propeptide of Type I collagen (P1NP) and intact osteocalcin (OC) or bone resorption markers of cross-linked N-telopeptide of type I collagen (NTX) and C-terminal telopeptide of type I collagen (CTX) between those with and without vascular calcification. *; $\mathrm{p}<0.05$.

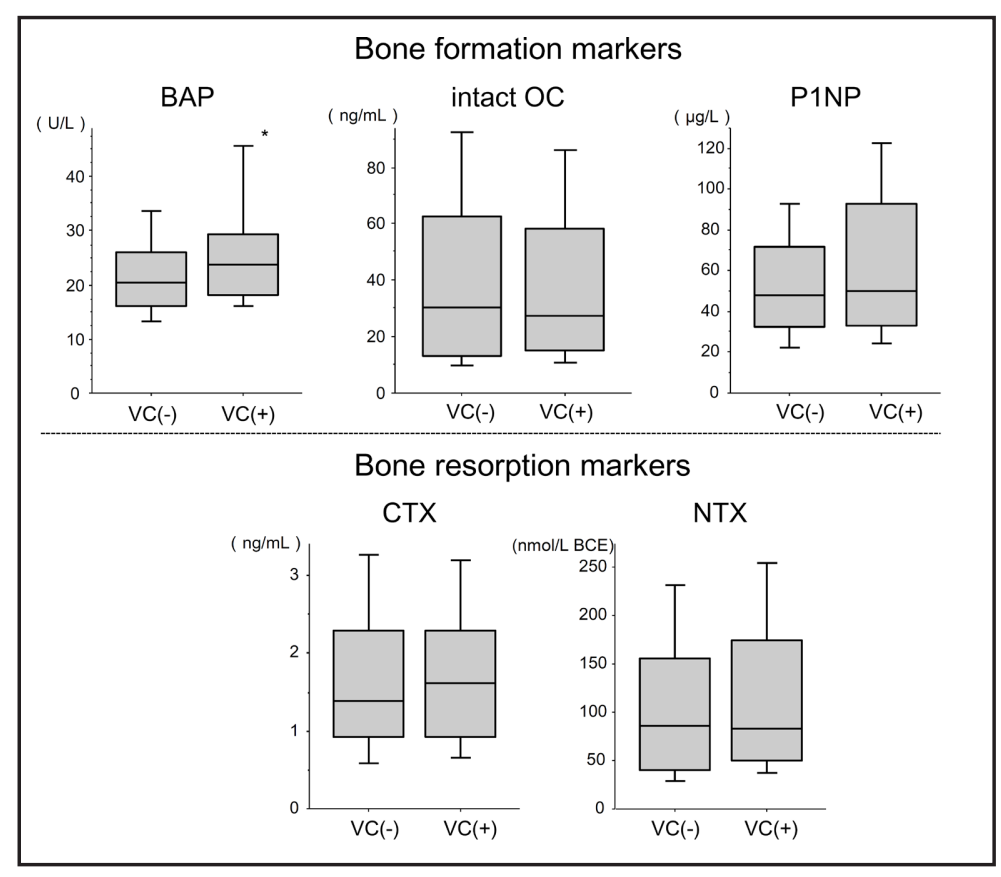

$(\mathrm{OR}, 1.030 ; 1.013-1.047 ; \mathrm{p}=0.0005)$, the presence of diabetes (OR, 20.566; 6.850-74.341; $\mathrm{p}<0.0001)$, lower levels of intact PTH (OR, 0.142; 95\% CI, 0.037-0.550; p =0.0047), and higher levels of serum BAP (OR, 366.784; 95\% CI, 10.603-12688.524; p = 0.0011). None of the other bone markers were associated with the presence of vascular calcification of the hand arteries. 


\section{Kidney Blood Pressure Research}

Kidney Blood Press Res 2014;39:299-307

\begin{tabular}{l|l}
\hline DOI: $10.1159 / 000355807$ & (C) 2014 S. Karger AG, Basel
\end{tabular}

Published onIIne: September 16, 2014

www.karger.com/kbr

Ishimura/Okuno/Okazaki/Norimine/Yamakawa/Yamakawa/Shoji/Nishizawa/Inaba: Bone Alkaline Phosphatase and Vascular Calcification

Multivariate logistic regression analyses were performed in order to explore the combined effect of factors associated with vascular calcification of the hand arteries. In this analysis, we focused on the association of BAP with vascular calcification, independent of each of the other bone markers. Through Models 2 to 5, log [BAP] was significantly and independently associated with vascular calcification after adjustment for age, duration of hemodialysis, $\log$ [intact $\mathrm{PTH}$ ] and vitamin $\mathrm{D}$ user, in addition to each of other bone markers of OC, P1NP, CTX and NTX, respectively (Table 2).

\section{Discussion}

In the present study, we examined the presence of vascular calcification of the hand arteries in male patients on stable maintenance hemodialysis, utilizing a simple method of roentgenography of the hands. The vascular calcification in the present study was comprised primarily of medial arterial calcification $[4,11,28]$. The hemodialysis duration in patients with vascular calcification, compared to those without, was significantly longer, PTH was significantly lower. The prevalence of vascular calcification in diabetic patients was significantly higher. These results are consistent with previous studies by others $[4,29$, $30]$ and us $[10,11]$. We found that, of the bone formation and resorption markers, serum levels of BAP were solely and significantly higher in patients with vascular calcification compared with those without, although other bone formation and resorption markers were not significantly different between the two groups. Furthermore, we found that serum BAP was significantly and independently associated with the presence of vascular calcification after adjustment for several confounders.

In the present study, we measured 3 bone formation markers and 2 bone resorption markers. BAP was strongly, significantly, and positively correlated with bone formation markers of P1NP and osteocalcin, and with bone resorption markers of CTX and NTX. This showed that BAP is a very strong indicator of bone turnover status. However, only BAP was significantly higher in patients with vascular calcification, compared with those without. This result suggests that BAP may exhibit a distinct association with vascular calcification, compared with other bone formation and resorption markers. In multivariate analyses of the present study, BAP was significantly independently associated with the presence of vascular calcification after adjustment for the duration of hemodialysis, diabetes, and PTH. BAP was also shown to be significantly and independently associated with further adjustment of each of the other bone markers, none of which were significantly associated with the presence of vascular calcification. This result also indicated that BAP exhibited a distinct, independent association with vascular calcification, and that higher BAP not only represents a bone turnover, but also a significant factor associated with vascular calcification.

Recently, alkaline phosphatase has been reported to be associated with vascular calcification in uremic patients [18]. Shantouf et al., reported as significant association of serum alkaline phosphatase with coronary artery calcification in maintenance hemodialysis patients [30]. Lomashvili et al., reported that alkaline phosphatase activity and protein were significantly increased in aorta in uremic rats [19]. They further showed that increased alkaline phosphatase lead to hydrolysis and inactivation of inorganic pyrophosphate [28, 31], which was a potent inhibitor of vascular calcification, in the aorta of uremic rats [19]. In their study, however, increased alkaline phosphatase was evaluated as a non-tissue specific alkaline phosphatase, not BAP. Concerning BAP, Iba et al., reported that serum BAP was significantly higher in osteoporosis patients with aortic calcification, compared with those without [26]. Osteoblast phenotypic transformation of vascular smooth muscle cells has been shown with aging, diabetes, hypercholesterolemia, hyperphosphatemia, mechanical abnormalities, and chronic renal insufficiency $[4,5,13,17,32,33]$. Thus, it may be considered that, under uremic condition, vascular smooth muscle cells transformed into osteoblastic cells, which in turn produce BAP, possibly leading to hydrolysis of pyrophosphate 


\section{Kidney \\ Blood Pressure Research}

Kidney Blood Press Res 2014;39:299-307

\begin{tabular}{l|l}
\hline DOI: $10.1159 / 000355807$ & C 2014 S. Karger AG, Basel
\end{tabular}

Published onIIne: September 16, 2014

www.karger.com/kbr

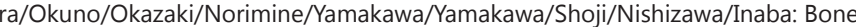
Alkaline Phosphatase and Vascular Calcification

and increased vascular calcification. Increased serum BAP in hemodialysis patients may represent, in part, osteoblastic transformation of vascular smooth muscle cells.

To the best of our knowledge, there have been no papers examining the relationship between bone formation/resorption markers and vascular calcification, although there have been a few studies that have shown a relationship between bone biopsy findings and coronary artery calcification which is a mixture of intimal and medial arterial calcification $[34,35]$. In these studies, low turnover status seen in bone biopsy was associated with coronary artery calcification, which is not medial artery calcification as was observed in the hand artery in our study. In the present study, we demonstrated that neither of the two bone formation nor the two resorption markers, except for BAP, were associated with medial arterial calcification of the hand artery. Our findings may indicate that there are no relationship between bone turnover markers and medial artery calcification. Our finding may also indicate a distinct function of BAP, not only as a marker of bone formation, but also as a marker of medial artery calcification. BAP may be a marker distinct from other bone formation and resorption markers, such as osteocalcin, PINP, CTX and NTX, in terms of a marker of medial arterial calcification.

There are some limitations to the present study. First, we assessed vascular calcification by plain hand roentgenography, which did not quantitatively assess vascular calcification and did not detect minute vascular calcification that would be invisible to the observer's detection. However, even though a simple method to detect vascular calcification in the present study was employed, factors associated with vascular calcification, such as diabetes, longer hemodialysis duration and lower PTH levels, were consistent with the previous studies $[4,10,11,30]$, suggesting that our method may be feasible in the evaluation of factors associated with vascular calcification. Second, the number of patients may be somewhat small. Further investigations are needed to examine large numbers of patients with precise and quantitative, or longitudinal assessment of vascular calcification. Third, we did not measure the levels of serum pyrophosphate, an inhibitor of vascular calcification, in the present study. The potential relationship between serum pyrophosphate levels and BAP will be interesting to examine in future investigations.

\section{Conclusion}

We found a significant association of BAP, but not other bone markers of osteocalcin, P1NP, CTX or NTX, with the presence of vascular calcification of the hand arteries of male hemodialysis patients, independent of diabetes, the duration of hemodialysis, and PTH. Serum BAP, which is a marker of bone turnover, may represent a distinct parameter of medial arterial calcification.

\section{Disclosure Statement}

All authors state that they have no conflicts of interest.

\section{References}

1 Blacher J, Guerin AP, Pannier B, Marchais SJ, London GM: Arterial calcifications, arterial stiffness, and cardiovascular risk in end-stage renal disease. Hypertension 2001;38:938-942.

-2 Guerin AP, Blacher J, Pannier B, Marchais SJ, Safar ME, London GM: Impact of aortic stiffness attenuation on survival of patients in end-stage renal failure. Circulation 2001;103:987-992. 


\section{Kidney \\ Blood Pressure Research}

Kidney Blood Press Res 2014;39:299-307

\begin{tabular}{l|l}
\hline DOI: 10.1159/000355807 & (c) 2014 S. Karger AG, Basel
\end{tabular}

Published onIIne: September 16, 2014

www.karger.com/kbr

Ishimura/Okuno/Okazaki/Norimine/Yamakawa/Yamakawa/Shoji/Nishizawa/Inaba: Bone Alkaline Phosphatase and Vascular Calcification

3 Sigrist MK, Taal MW, Bungay P, McIntyre CW: Progressive vascular calcification over 2 years is associated with arterial stiffening and increased mortality in patients with stages 4 and 5 chronic kidney disease. Clin J Am Soc Nephrol 2007;2:1241-1248.

4 Thompson B, Towler DA: Arterial calcification and bone physiology: Role of the bone-vascular axis. Nat Rev Endocrinol 2012;8:529-543.

-5 Vattikuti R, Towler DA: Osteogenic regulation of vascular calcification: An early perspective. Am J Physiol Endocrinol Metab 2004;286:E686-696.

-6 Aoun S, Blacher J, Safar ME, Mourad JJ: Diabetes mellitus and renal failure: Effects on large artery stiffness. J Hum Hypertens 2001;15:693-700.

-7 Block GA, Spiegel DM, Ehrlich J, Mehta R, Lindbergh J, Dreisbach A, Raggi P: Effects of sevelamer and calcium on coronary artery calcification in patients new to hemodialysis. Kidney Int 2005;68:1815-1824.

-8 Chertow GM, Raggi P, Chasan-Taber S, Bommer J, Holzer H, Burke SK: Determinants of progressive vascular calcification in haemodialysis patients. Nephrol Dial Transplant 2004;19:1489-1496.

-9 Stompor TP, Pasowicz M, Sulowicz W, Dembinska-Kiec A, Janda K, Wojcik K, Tracz W, Zdzienicka A, Konieczynska M, Klimeczek P, Janusz-Grzybowska E: Trends and dynamics of changes in calcification score over the 1-year observation period in patients on peritoneal dialysis. Am J Kidney Dis 2004;44:517-528.

10 Ishimura E, Okuno S, Kitatani K, Kim M, Shoji T, Nakatani T, Inaba M, Nishizawa Y: Different risk factors for peripheral vascular calcification between diabetic and non-diabetic haemodialysis patients--importance of glycaemic control. Diabetologia 2002;45:1446-1448.

11 Ishimura E, Okuno S, Kitatani K, Maekawa K, Izumotani T, Yamakawa T, Jono S, Shoji T, Shioi A, Inaba M, Massry SG, Nishizawa Y: C-reactive protein is a significant predictor of vascular calcification of both aorta and hand arteries. Semin Nephrol 2004;24:408-412.

-12 Kiel DP, Kauppila LI, Cupples LA, Hannan MT, O'Donnell CJ, Wilson PWF: Bone loss and the progression of abdominal aortic calcification over a 25 year period: The framingham heart study. Calcified Tissue Int 2001;68:271-276.

13 Bostrom KI: Cell differentiation in vascular calcification. Z Kardiol 2000;89:69-74.

$>14$ Bucay N, Sarosi I, Dunstan CR, Morony S, Tarpley J, Capparelli C, Scully S, Tan HL, Xu WL, Lacey DL, Boyle WJ, Simonet WS: Osteoprotegerin-deficient mice develop early onset osteoporosis and arterial calcification. Gene Dev 1998;12:1260-1268.

15 Luo GB, Ducy P, McKee MD, Pinero GJ, Loyer E, Behringer RR, Karsenty G: Spontaneous calcification of arteries and cartilage in mice lacking matrix gla protein. Nature 1997;386:78-81.

16 London GM: Bone-vascular cross-talk. J Nephrol 2012;25:619-625.

17 Cannata-Andia JB, Roman-Garcia P, Hruska K: The connections between vascular calcification and bone health. Nephrol Dial Transplant 2011;26:3429-3436.

18 Schoppet M, Shanahan CM: Role for alkaline phosphatase as an inducer of vascular calcification in renal failure? Kidney Int 2008;73:989-991.

19 Lomashvili KA, Garg P, Narisawa S, Millan JL, O'Neill WC: Upregulation of alkaline phosphatase and pyrophosphate hydrolysis: Potential mechanism for uremic vascular calcification. Kidney Int 2008;73:1024-1030.

-20 Regidor DL, Kovesdy CP, Mehrotra R, Rambod M, Jing J, McAllister CJ, Van Wyck D, Kopple JD, KalantarZadeh K: Serum alkaline phosphatase predicts mortality among maintenance hemodialysis patients. J Am Soc Nephrol 2008;19:2193-2203.

-21 Kobayashi I, Shidara K, Okuno S, Yamada S, Imanishi Y, Mori K, Ishimura E, Shoji S, Yamakawa T, Inaba M: Higher serum bone alkaline phosphatase as a predictor of mortality in male hemodialysis patients. Life Sci 2012;90:212-218.

22 Okuno S, Ishimura E, Norimine K, Tsuboniwa N, Kagitani S, Yamakawa K, Yamakawa T, Sato KK, Hayashi T, Shoji S, Nishizawa Y, Inaba M: Serum adiponectin and bone mineral density in male hemodialysis patients. Osteoporos Int 2012;23:2027-2035.

23 Maeno Y, Inaba M, Okuno S, Yamakawa T, Ishimura E, Nishizawa Y: Serum concentrations of cross-linked n-telopeptides of type I collagen: New marker for bone resorption in hemodialysis patients. Clin Chem 2005;51:2312-2317.

24 Okuno S, Inaba M, Kitatani K, Ishimura E, Yamakawa T, Nishizawa Y: Serum levels of c-terminal telopeptide of type i collagen: A useful new marker of cortical bone loss in hemodialysis patients. Osteoporos Int 2005;16:501-509. 


\section{Kidney \\ Blood Pressure Research}

\section{Kidney Blood Press Res 2014;39:299-307}

DOI: 10.1159/000355807

Published online: September 16, 2014

(C) 2014 S. Karger AG, Basel

www.karger.com/kbr

Ishimura/Okuno/Okazaki/Norimine/Yamakawa/Yamakawa/Shoji/Nishizawa/Inaba: Bone Alkaline Phosphatase and Vascular Calcification

25 Ueda M, Inaba M, Okuno S, Nagasue K, Kitatani K, Ishimura E, Shimizu M, Miki T, Kim M, Nishizawa Y: Clinical usefulness of the serum n-terminal propeptide of type i collagen as a marker of bone formation in hemodialysis patients. Am J Kidney Dis 2002;40:802-809.

26 Iba K, Takada J, Yamashita T: The serum level of bone-specific alkaline phosphatase activity is associated with aortic calcification in osteoporosis patients. J Bone Miner Metab 2004;22:594-596.

27 Gomez B, Jr., Ardakani S, Ju J, Jenkins D, Cerelli MJ, Daniloff GY, Kung VT: Monoclonal antibody assay for measuring bone-specific alkaline phosphatase activity in serum. Clin Chem 1995;41:1560-1566.

-28 O'Neill WC, Sigrist MK, McIntyre CW: Plasma pyrophosphate and vascular calcification in chronic kidney disease. Nephrol Dial Transplant 2010;25:187-191.

29 Goodman WG, Goldin J, Kuizon BD, Yoon C, Gales B, Sider D, Wang Y, Chung J, Emerick A, Greaser L, Elashoff RM, Salusky IB: Coronary-artery calcification in young adults with end-stage renal disease who are undergoing dialysis. New Engl J Med 2000;342:1478-1483.

-30 Shantouf R, Kovesdy CP, Kim Y, Ahmadi N, Luna A, Luna C, Rambod M, Nissenson AR, Budoff MJ, KalantarZadeh K: Association of serum alkaline phosphatase with coronary artery calcification in maintenance hemodialysis patients. Clin J Am Soc Nephrol 2009;4:1106-1114.

-31 Ketteler M, Biggar PH: What dishwashers and humans have in common. Nephrol Dial Transplant 2010;25:4-6.

-32 Jono S, McKee MD, Murry CE, Shioi A, Nishizawa Y, Mori K, Morii H, Giachelli CM: Phosphate regulation of vascular smooth muscle cell calcification. Circ Res 2000;87:E10-17.

-33 Shao JS, Cai J, Towler DA: Molecular mechanisms of vascular calcification: Lessons learned from the aorta. Arterioscler Thromb Vasc Biol 2006;26:1423-1430.

-34 Barreto DV, Barreto Fde C, Carvalho AB, Cuppari L, Draibe SA, Dalboni MA, Moyses RM, Neves KR, Jorgetti V, Miname M, Santos RD, Canziani ME: Association of changes in bone remodeling and coronary calcification in hemodialysis patients: A prospective study. Am J Kidney Dis 2008;52:1139-1150.

-35 Tomiyama C, Carvalho AB, Higa A, Jorgetti V, Draibe SA, Canziani ME: Coronary calcification is associated with lower bone formation rate in ckd patients not yet in dialysis treatment. J Bone Miner Res 2010;25:499-504. 